\title{
Properties of heparin binding to purified plasma membranes from bovine granulosa cells*
}

\author{
M. A. Winer and R. L. Ax \\ Department of Dairy Science and the Endocrinology-Reproductive Physiology Program, \\ University of Wisconsin, 1675 Observatory Drive, Madison, WI 53706, USA
}

\begin{abstract}
Summary. Bovine granulosa cells were disrupted by nitrogen cavitation and the resulting membrane vesicles were isolated by centrifugation using a self-generating Percoll gradient. Transmission electron microscopy and marker enzyme assays revealed a highly enriched preparation of plasma membrane vesicles with little contamination from intracellular organelles. The membranes were examined for their ability to bind $\left[{ }^{3} \mathrm{H}\right]$ heparin under a variety of physical conditions. Binding was dependent largely on electrostatic interactions which were sensitive to alterations in the ionic strength and $\mathrm{pH}$ of the medium. Optimal binding was obtained in the absence of added salt and at pH 6.5 but reduced by $50 \%$ at $150 \mathrm{~mm}-\mathrm{NaCl}$ or at $\mathrm{pH}$ values above $7 \cdot 5$. Heparin binding to the membranes was abolished by a 1-h pretreatment with chymotrypsin, plasmin, pronase or trypsin. Detergent treatment of the membranes had various effects, depending on the ionic characteristics of the detergents used. Sodium dodecyl sulphate-polyacrylamide gels of plasma membrane proteins revealed a complex pattern of polypeptides with $M_{\mathrm{r}}$ of 10000-120000. Autoradiographic analysis of plasma membrane proteins on Western blots labelled with ${ }^{125}$ I-labelled heparin revealed 3 major heparin-binding proteins with molecular weights of $14000-16000$. These studies report a new method of rapidly obtaining purified membranes from a limited population of granulosa cells. The characterization of the binding domains as membraneassociated proteins provides opportunities for numerous additional studies. Detergent solubilization of the membranes without appreciable loss in binding activity should simplify attempts to purify the binding proteins. Further analysis of the interactions of these molecules with native follicular fluid GAGs at various stages of granulosa cell development should provide useful insights into the role of complex carbohydrates in follicular maturation.
\end{abstract}

Keywords: binding proteins; cattle; granulosa cells; heparin; plasma membranes

\section{Introduction}

During follicular development, granulosa cells produce the complex carbohydrates, glycosaminoglycans (GAGs), as constituents of proteoglycans. These proteoglycans are secreted into the follicular fluid (Ax et al., 1985), and may become incorporated into the extracellular matrix as in other tissue types (Lindahl \& Hook, 1978; Hook et al., 1984). The production of GAGs by granulosa cells is under hormonal control (for review, see Ax et al., 1985; Ax \& Bellin, 1988). GAGs stimulate the appearance of gonadotrophin receptors on granulosa cells cultured in vitro (Nimrod \& Lindner, 1980; Campbell \& Valiquett, 1982). Conversely, follicular GAGs inhibit gonadotrophin binding to cell surface receptors (Amsterdam et al., 1979; Nimrod \& Lindner, 1980) possibly by steric

\footnotetext{
*Reprint requests to: Dr R. L. Ax.
} 
hindrance (Hook et al., 1984). They inhibit progesterone secretion (Campbell \& Valiquett, 1982; Bellin et al., 1987a; Ledwitz-Rigby et al., 1987), and may inhibit steroidogenesis indirectly by altering the uptake and degradation of lipoproteins (Bellin et al., 1987a).

The two predominant GAGs present in bovine follicular fluid are dermatan sulphate and heparan sulphate (Bellin \& Ax, 1987). Both are composed of repeating disaccharide units (iduronic acid and $\mathrm{N}$-acetylgalactosamine for dermatan sulphate, and glucuronic acid and $\mathrm{N}$-acetylglucosamine for heparan sulphate). Both contain various amounts of $\mathrm{N}$ - and $\mathrm{O}$-linked sulphate groups. The commercially available GAG, heparin, is similar to heparan sulphate in that they both contain $\mathrm{N}$. sulphated glucosamine residues. Since heparin contains a high percentage of iduronic acid residues, it is also chemically similar to dermatan sulphate. It therefore makes a useful and readily available probe to examine the ability of follicular fluid GAGs to interact with granulosa cells.

Bovine granulosa cells are capable of binding $\left[{ }^{3} \mathrm{H}\right]$ heparin in a fashion typical for receptorligand interactions (Ax et al., 1984; Bushmeyer et al., 1985). Using crude membrane preparations from bovine granulosa cells, Bushmeyer et al. (1985) demonstrated that $\left[{ }^{3} \mathrm{H}\right]$ heparin binding was specific, saturable, reversible, and dependent on the $\mathrm{pH}$ and ionic composition of the medium. Other factors which influence GAG binding to granulosa cells include the maturation state of the follicle from which the cells are obtained (Ax et al., 1984; Bushmeyer et al., 1985; Bellin et al., 1987b), and the presence of GAGs already attached to the cell surface (Ax et al., 1986). The degree of sulphation of the GAG has also been shown to affect binding to mouse tumour cells (Winterbourne \& Mora, 1981) and granulosa cells (Bellin et al., 1987b).

If soluble proteoglycans/GAGs in the follicular fluid or GAGs in the extracellular matrix are to modulate granulosa cell function directly, they must interact with the cell surface (for review, see Hook et al., 1984). These studies describe a method for obtaining a purified preparation of plasma membranes from bovine granulosa cells. After confirming the purity of the membrane fraction, studies were performed to ensure that the characteristics of heparin binding to the purified membranes had not been altered by the procedure. Specific heparin-binding proteins in the membranes were then identified by their ability to bind radiolabelled heparin.

\section{Materials and Methods}

\section{Granulosa cell membrane isolation}

Ovaries were obtained within $30 \mathrm{~min}$ of slaughter of cows (Packerland, Green Bay, WI, USA) and follicular fluid was vacuum aspirated from small ( $<5 \mathrm{~mm}$ diam.) follicles. Granulosa cells were collected from $50 \mathrm{ml}$ follicular fluid by centrifugation at $1750 \mathrm{~g}$ for $15 \mathrm{~min}$ and resuspended in isolation buffer $(40 \mathrm{mM}$-Tris, $150 \mathrm{~mm}-\mathrm{NaCl}, 2 \mathrm{~mm}$-ethylene diamine tetraacetic acid (EDTA), $10 \mathrm{~mm}$-benzamidine, $2 \mu \mathrm{M}$-phenyl methyl sulphonyl fluoride, $2 \mu \mathrm{M}$-pepstatin $\mathrm{A}$ and $0.01 \%$ sodium azide, $\mathrm{pH} 7.35$ ). Granulosa cells were separated from red blood cells by centrifugation through a Percoll (Sigma Chemical Co., St Louis, MO, USA) cushion (isolation buffer:Percoll, 2:1, v/v) at $1750 \mathrm{~g}$ for $15 \mathrm{~min}$. The layer of flocculent material on top of the cushion was aspirated, diluted with $20 \mathrm{ml}$ isolation buffer and washed by centrifugation at $1750 \mathrm{~g}$ for $15 \mathrm{~min}$. The resulting pellet was resuspended in $1 \mathrm{ml}$ isolation buffer and stored frozen in liquid nitrogen until use. Typically, this procedure yielded $25 \pm 3.7 \mathrm{mg}$ granulosa cell protein per preparation $(n=12)$.

Thawed cells were diluted to $5 \mathrm{ml}$ with isolation buffer and subjected to nitrogen cavitation in a Parr Cell Disruption Bomb (Parr Instrument Co., Moline, IL, USA) for 5 min (equilibration time) at $600 \mathrm{psi}(4140 \mathrm{kPa})$. Cellular debris was washed from the suspension of cavitated cells by centrifugation at $1000 \mathrm{~g}, 10 \mathrm{~min}$. The supernatant fluid was decanted and the pellet washed twice by resuspension in $2 \mathrm{ml}$ isolation buffer and centrifugation at $1000 \mathrm{~g}$ for $10 \mathrm{~min}$. The supernatant fractions were pooled, adjusted to $12.5 \mathrm{ml}$ with isolation buffer and mixed with $6.8 \mathrm{ml}$ Percoll and $0.7 \mathrm{ml} 1.5 \mathrm{M}-\mathrm{NaCl}$. The suspension was centrifuged for $30 \mathrm{~min}$ at $60000 \mathrm{~g}_{\text {ave }}$ in a Beckman 60Ti rotor. The bands resolved by the self-generating Percoll gradient were aspirated, diluted to approximately $20 \mathrm{ml}$ with isolation buffer and washed from the Percoll by centrifugation at $150000 \mathrm{~g}_{\text {ave }}$ for $1 \mathrm{~h}$. The resulting pellets were used for all morphological and biochemical studies.

\section{Electron microscopy}

Samples for electron microscopy were fixed as pellets with $4 \%$ glutaraldehyde in $0 \cdot 1 \mathrm{M}$-cacodylate buffer, postfixed in $1 \%$ osmium tetraoxide, dehydrated with a graded series of ethanols, treated with propylene oxide and 
embedded in Eponate 812 (Ted Pella, Inc., Tustin, CA, USA). Thin sections were stained with uranyl acetate and lead citrate and viewed with an Hitachi $\mathrm{H}-600$ electron microscope at $75 \mathrm{kV}$.

\section{Enzyme assays}

The distribution and recoveries of various cell membrane fractions were determined during the purification procedure by assaying for glucose 6-phosphatase, $5^{\prime}$-nucleotidase and succinate-cytochrome c reductase activities as organelle-specific marker enzymes for microsomal, plasma, and mitochondrial membranes, respectively. Glucose 6-phosphatase and 5'-nucleotidase assays were performed using the reagents of Aronson \& Touster (1974). The incubations were terminated by the addition of $2.5 \%$ sodium dodecyl sulphate (SDS). Enzyme activities were determined by measuring the amount of inorganic phosphate produced by hydrolysis of glucose 6-phosphate or adenosine monophosphate during a 20-min incubation. Basal amounts of phosphate present in each sample were determined by addition of SDS to the assay medium before addition of the sample. Inorganic phosphate was determined in each sample by a non-automated spectrophotometric procedure using the reagents of Hegyvary et al. (1979). Succinatecytochrome $c$ reductase was assayed by the method of King (1967) with 2,6-dichlorophenolindophenol as an acceptor. All samples were assayed for each type of enzyme activity in duplicate.

\section{$\left.l^{3} H\right]$ Heparin binding assay}

Purified plasma membranes were resuspended in isolation buffer to a concentration of $30 \mu \mathrm{g}$ protein $/ \mathrm{ml}$. Samples of $100 \mu \mathrm{l}$ were placed on nitrocellulose filters in Millititer HA 96-well filtration plates (Millipore Corp., Bedford, MA, USA) (Miller \& Ax, 1988). The samples were washed 3 times with Tris buffer ( $40 \mathrm{~mm}$-Tris, pH 7.35) by vacuum filtration and incubated for $2 \mathrm{~h}$ at $39^{\circ} \mathrm{C}$ in the presence of $3300 \mathrm{nM}-\left[{ }^{3} \mathrm{H}\right]$ heparin (sp. act. $0.4 \mathrm{mCi} / \mathrm{mg}$ : New England Nuclear Research Products, Boston, MA, USA) in a final volume of $200 \mu 1$. After incubation the samples were vacuum filtered and washed 3 times with Tris buffer to remove unbound heparin. The filters were punched from the plates into scintillation vials and $5 \mathrm{ml}$ Ecoscint scintillation cocktail (National Diagnostics, Manville, NJ, USA) was added to each vial. $\left[{ }^{3} \mathrm{H}\right]$ heparin binding was quantified by liquid scintillation spectrophotometry. Binding assays were performed in triplicate. The effects of non-specific binding were not assessed as previous studies indicated negligible non-specific binding to granulosa cell membranes with this assay system (Winer, 1987).

As a prelude to the identification of specific heparin-binding moieties, the efficacy of heparin binding to plasma membranes was tested under various physical conditions. The ability of increasing ionic strength to displace bound heparin was examined by incubating isolated membranes with $\left[{ }^{3} \mathrm{H}\right]$ heparin and washing as described above, then re-incubating for $2 \mathrm{~h}$ in the presence of 0 to $1 \mathrm{M}-\mathrm{NaCl}$. After incubation the samples were filtered, washed, and counted as above. The effects of $\mathrm{pH}$ were examined by incubation of the samples with $3300 \mathrm{nM}-\left[^{3} \mathrm{H}\right] \mathrm{heparin}$ in $300 \mathrm{mM}$-Tris in a final volume of $200 \mu \mathrm{l}$ at $\mathrm{pH}$ values ranging from 5.5 to 9.0 . The effects of divalent cations on binding of the polyanionic GAG to the membranes were examined by incubation of the samples in the presence of $0-100 \mathrm{mM}-\mathrm{CaCl}_{2},-\mathrm{MgCl}_{2}$, or -EDTA.

The effects of perturbations of the protein and lipid constituents of the membranes on heparin binding were also examined by treatment of the membranes with proteases and detergents. For the protease studies, membranes were vacuum aspirated onto nitrocellulose filters, washed with Tris buffer, and preincubated for $1 \mathrm{~h}$ in chymotrypsin (Type VII), plasmin, pronase E (protease Type XIV from Streptomyces griseus) or trypsin (Type IX) (all from Sigma) at $1 \mu \mathrm{g} / \mathrm{ml}$ in a final volume of $200 \mu \mathrm{l}$. After preincubation the samples were washed 4 times with Tris buffer to remove excess proteases and re-incubated with radiolabelled heparin as described previously. Control incubations were performed with $\left[{ }^{3} \mathrm{H}\right]$ heparin and enzymes, but no plasma membranes.

For detergent studies, membranes were vacuum aspirated onto nitrocellulose filters, washed with Tris buffer, and preincubated for $1 \mathrm{~h}$ with detergents with different ionic properties $(0 \cdot 1 \%$ solutions of cholic acid, 3-[(3-cholamidopropyl)-dimethylammonio]-1-propane-sulphonate (CHAPS), Nonidet P-40, SDS, Triton X-100 or pH 9.0 Tris buffer) in a final volume of $200 \mu$. After pre-incubation the samples were washed 4 times with Tris buffer to remove excess detergents and re-incubated with radiolabelled heparin as described above. Radiolabelling was performed in the presence or absence of detergents.

\section{Electrophoresis and autoradiography}

Samples were solubilized in electrophoresis sample buffer under non-reducing conditions. Then $10 \mu \mathrm{g}$ (for silver-stained gels) or $40 \mu \mathrm{g}$ (for electrophoretic transfers) of membrane protein were subjected to one-dimensional sodium dodecyl sulphate-polyacrylamide gel electrophoresis (SDS-PAGE; Laemmli, 1970). Proteins were visualized by silver staining (Wray et al., 1981) or transferred electrophoretically to nitrocellulose paper (Burnette, 1981). The nitrocellulose sheets were incubated for $2 \mathrm{~h}$ with $2 \mu \mathrm{g}{ }^{125} \mathrm{I}$-labelled heparin $/ \mathrm{ml}$ (sp. act. $0.224 \mathrm{mCi} / \mathrm{mg}$ ) (Bolton \& Hunter, 1973; Cardin et al., 1984) in labelling buffer ( $40 \mathrm{~mm}$-Tris, pH 6.5) containing 0.05\% Tween-20 to reduce non-specific adsorption of heparin to the nitrocellulose (Cardin et al., 1984; Smith \& Knauer, 1987). The sheets were 
washed with labelling buffer, dried, and subjected to autoradiographic analysis. Specificity of binding was assessed by subsequent reincubation with $1 \mathrm{mg}$ unlabelled heparin/ml.

\section{Protein assay}

Samples were solubilized by boiling for $15 \mathrm{sec}$ in the presence of $1 \mathrm{M}-\mathrm{NaOH}$ and $25 \mathrm{~mm}-2$-mercaptoethanol. Protein concentration was determined by the method of Bradford (1976) using bovine gamma globulin as a standard.

\section{Statistics}

All data for the enzyme assays represent the mean \pm s.e. for 3 separate membrane isolations. Data are expressed both as specific activities and percentage recovery of total activity. All data for the heparin-binding assays are the mean \pm s.e. for 2 separate membrane isolations. Data were analysed statistically using analysis of variance and the Fisher test of least significant difference.

\section{Results}

\section{Morphological and enzymic characterization of isolated granulosa cell plasma membranes}

The Percoll gradient separated the $1000 \mathrm{~g}$ supernatant fraction of the cavitated granulosa cells into 3 distinct bands with relative densities of $1.0,1.005$ and $1.057 \mathrm{~g} / \mathrm{ml}$, respectively. Electron microscopy of Band 1 indicated that it was composed of a homogeneous suspension of membrane vesicles with no apparent contamination from intact intracellular organelles such as mitochondria, nuclei, or stacks of Golgi bodies (Fig. 1). The specific activity of the plasma membrane marker

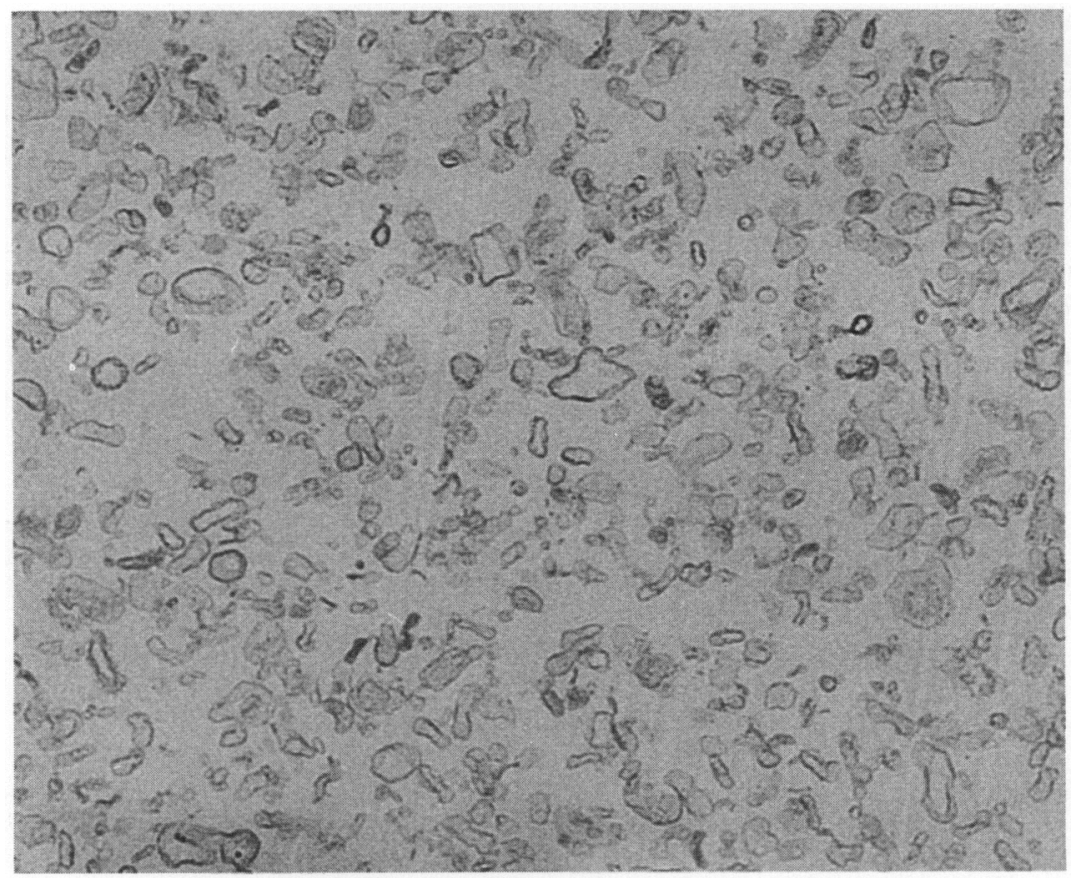

Fig. 1. Transmission electron micrograph of Band 1 obtained from the Percoll gradient separation of the $1000 \mathrm{~g}$ supernatant fluid of the nitrogen-cavitated granulosa cells. The vesicles are homogeneous in size and the fraction contains no intact intracellular organelles. $\times 9700$. 
Table 1. Summary of specific activities and percentage recoveries for plasma, microsomal and mitochondrial marker enzymes from various fractions obtained during the granulaosa cell fractionation procedure

\begin{tabular}{|c|c|c|c|c|c|c|}
\hline \multirow[b]{2}{*}{ Sample } & \multicolumn{2}{|c|}{ 5'-nucleotidase } & \multicolumn{2}{|c|}{$\begin{array}{l}\text { Glucose 6- } \\
\text { phosphatase }\end{array}$} & \multicolumn{2}{|c|}{$\begin{array}{l}\text { Succinate-cytochrome } \\
\text { c reductase }\end{array}$} \\
\hline & Sp. act.* & $\begin{array}{l}\% \text { of } \\
\text { total } \\
\text { activity }\end{array}$ & Sp. act.* & $\begin{array}{l}\% \text { of } \\
\text { total } \\
\text { activity }\end{array}$ & Sp. act. $†$ & $\begin{array}{c}\% \text { of } \\
\text { total } \\
\text { activity }\end{array}$ \\
\hline Cavitate & $\begin{array}{c}24 \cdot 31 \pm \\
2 \cdot 58\end{array}$ & 100 & $\begin{array}{c}12 \cdot 98 \pm \\
1.40\end{array}$ & 100 & $\begin{array}{c}0.022 \pm \\
0.002\end{array}$ & 100 \\
\hline $1000 \mathrm{~g}$ pellet & $\begin{array}{c}11 \cdot 07 \pm \\
5.71\end{array}$ & $\begin{array}{c}13 \cdot 1 \pm \\
6 \cdot 2\end{array}$ & $\begin{array}{c}9 \cdot 26 \pm \\
2 \cdot 69\end{array}$ & $\underset{5 \cdot 5}{21 \cdot 2 \pm}$ & $\begin{array}{c}0.025 \pm \\
0.015\end{array}$ & $\begin{array}{l}33 \cdot 5 \pm \\
18 \cdot 2\end{array}$ \\
\hline $1000 \mathrm{~g}$ supernatant & $\begin{array}{c}28.51 \pm \\
7.60\end{array}$ & $\begin{array}{c}63 \cdot 8 \pm \\
9 \cdot 3\end{array}$ & $\begin{array}{c}9.07 \pm \\
1.43\end{array}$ & $\begin{array}{l}40 \cdot 3 \pm \\
8 \cdot 2\end{array}$ & $\begin{array}{c}0.024 \pm \\
0.004\end{array}$ & $\begin{array}{c}62 \cdot 9 \pm \\
10 \cdot 6\end{array}$ \\
\hline Percoll Band 1 & $\begin{array}{c}96.91 \pm \\
22.03\end{array}$ & $\begin{array}{c}7.9 \pm \\
3 \cdot 3\end{array}$ & $\begin{array}{c}10 \cdot 04 \pm \\
2.78\end{array}$ & $\begin{array}{c}1 \cdot 1 \pm \\
0 \cdot 2\end{array}$ & $\begin{array}{c}0.03 \pm \\
0.01\end{array}$ & $\begin{array}{c}1.9 \pm \\
0.3\end{array}$ \\
\hline Percoll Band 2 & $\begin{array}{c}63 \cdot 74 \pm \\
10 \cdot 51\end{array}$ & $\begin{array}{c}17 \cdot 9 \pm \\
1.2\end{array}$ & $\begin{array}{c}20 \cdot 68 \pm \\
5 \cdot 35\end{array}$ & $\begin{array}{l}11.0 \pm \\
2.9\end{array}$ & $\begin{array}{c}0.015 \pm \\
0.009\end{array}$ & $\begin{array}{c}5 \cdot 5 \pm \\
3 \cdot 0\end{array}$ \\
\hline Percoll Band 3 & $\begin{array}{c}19.90 \pm \\
1.78\end{array}$ & $\underset{1 \cdot 0}{21 \cdot 1 \pm}$ & $\begin{array}{c}8.95 \pm \\
3.73\end{array}$ & $\begin{array}{c}16 \cdot 3 \pm \\
5 \cdot 2\end{array}$ & $\begin{array}{c}0.024 \pm \\
0.004\end{array}$ & $\begin{array}{c}28 \cdot 8 \pm \\
5 \cdot 5\end{array}$ \\
\hline
\end{tabular}

Values represent mean \pm s.e.m. for 3 separate isolations.

*Expressed as $\mathrm{nmol}$ inorganic phosphate produced/min/mg protein.

$\nmid$ Data are expressed as $\mu \mathrm{mol}$ succinate oxidized $/ \mathrm{min} / \mathrm{mg}$ protein.

Table 2. Summary of percentage recoveries of total protein and heparin binding and specific activities of heparin binding to various fractions obtained during the granulosa cell fractionation procedure

\begin{tabular}{lcccc}
\hline & Protein & & \multicolumn{2}{c}{ Heparin binding } \\
\cline { 2 - 5 } \cline { 5 - 5 } Sample & $\begin{array}{c}\% \text { of } \\
\text { total protein* }\end{array}$ & & $\begin{array}{c}\% \text { of } \\
\text { total binding } \dagger\end{array}$ & Sp. act. $\neq$ \\
\hline Cavitate & 100 & & 100 & $1.56 \pm 0.09$ \\
$1000 \mathrm{~g}$ pellet & $36.43 \pm 4.47$ & & $38.2 \pm 0.2$ & $1.49 \pm 0.14$ \\
$1000 \mathrm{~g}$ supernatant & $64.62 \pm 3.97$ & & $29.8 \pm 1.5$ & $0.62 \pm 0.02$ \\
Percoll Band 1 & $2.83 \pm 1.13$ & & $1.2 \pm 0.2$ & $0.49 \pm 0.16$ \\
Percoll Band 2 & $7.64 \pm 1.04$ & & $2.1 \pm 0.4$ & $0.49 \pm 0.01$ \\
Percoll Band 3 & $20.89 \pm 2.85$ & & $23.5 \pm 1.4$ & $1.35 \pm 0.15$ \\
\hline
\end{tabular}

* Mean \pm s.e.m. for 5 separate membrane isolations.

†Mean \pm s.e.m. for 3 separate membrane isolations.

$\ddagger$ Expressed as pmol tritiated heparin bound/ $\mu \mathrm{g}$ protein.

enzyme 5 -nucleotidase was enriched 4-fold (Table 1). There was no corresponding increase in the activity of the microsomal (glucose 6-phosphatase) or mitochondrial (succinate-cytochrome c reductase) enzymes. Approximately $8 \%$ of the 5 -nucleotidase activity present in the original cavitated sample appeared in the first band of the Percoll gradient, with only $1-2 \%$ of the enzymes from intracellular organelles present in that fraction (Table 1). The top band was designated the plasma membrane fraction and used for all subsequent binding studies. 


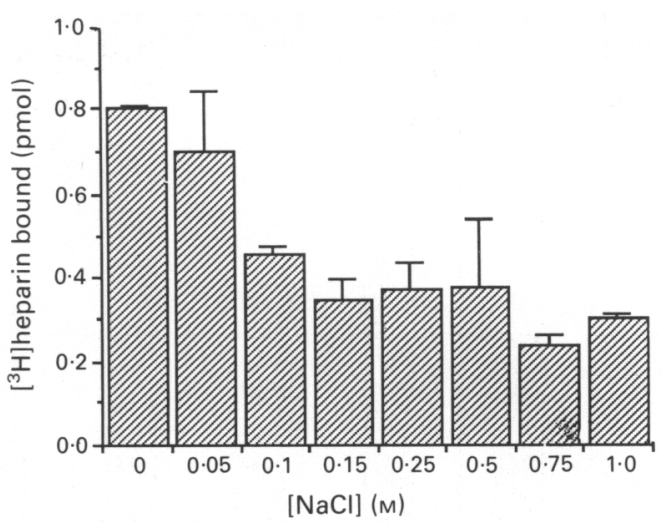

Fig. 2. Purified bovine granulosa cell plasma membranes were labelled for $2 \mathrm{~h}$ with $\left[{ }^{3} \mathrm{H}\right]-$ heparin, washed with Tris buffer, and re-incubated for $1 \mathrm{~h}$ in the indicated concentrations of $\mathrm{NaCl}$. Values are the mean \pm s.e. of 2 separate membrane preparations.

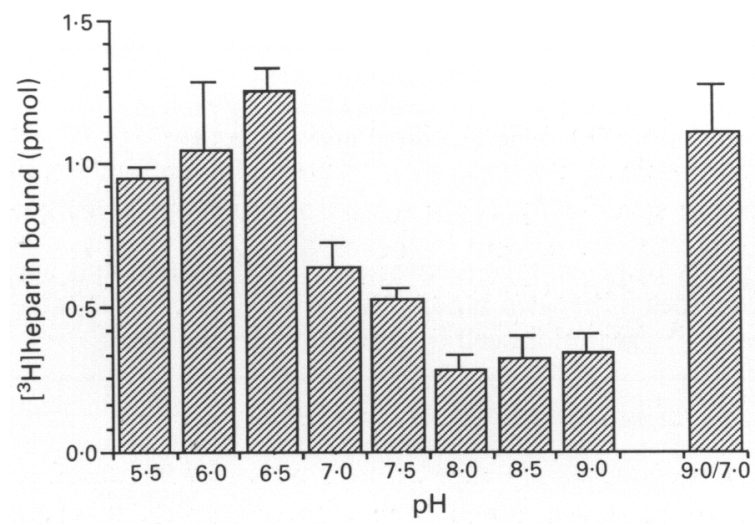

Fig. 3. Purified bovine granulosa cell plasma membranes were labelled for $2 \mathrm{~h}$ with $\left[{ }^{3} \mathrm{H}\right]$ heparin at the indicated $\mathrm{pH}$. Values are the mean \pm s.e. of 2 separate membrane preparations. The samples indicated at $9 \cdot 0 / 7 \cdot 0$ were pre-incubated for $1 \mathrm{~h}$ at $\mathrm{pH} \mathrm{9.0}$ and washed with Tris buffer before exposure to $\left[{ }^{3} \mathrm{H}\right]$ heparin at $\mathrm{pH} 7 \cdot 0$.
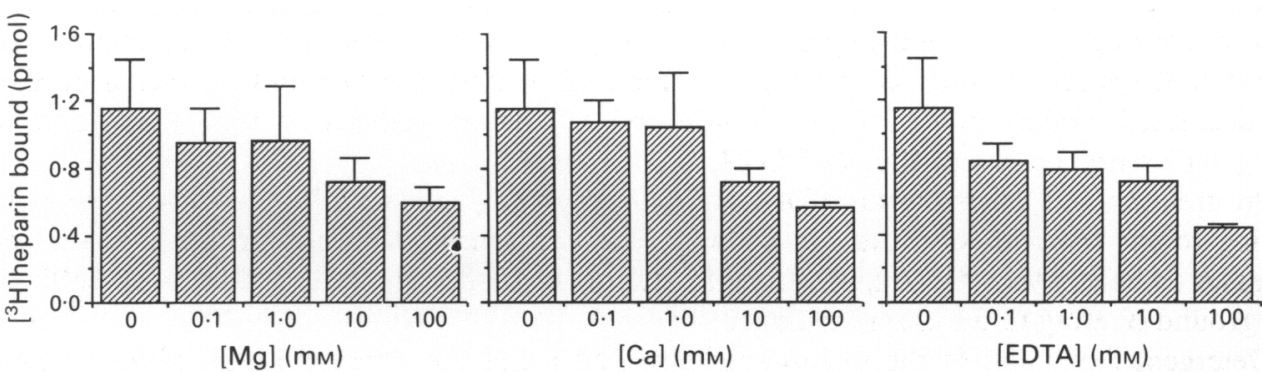

Fig. 4. Purified bovine granulosa cell plasma membranes were labelled for $2 \mathrm{~h}$ with $\left[{ }^{3} \mathrm{H}\right] \mathrm{heparin}$ in the presence of the indicated concentrations of $\mathrm{MgCl}_{2}, \mathrm{CaCl}_{2}$, or EDTA. Values are the mean \pm s.e. of 2 separate membrane preparations. 


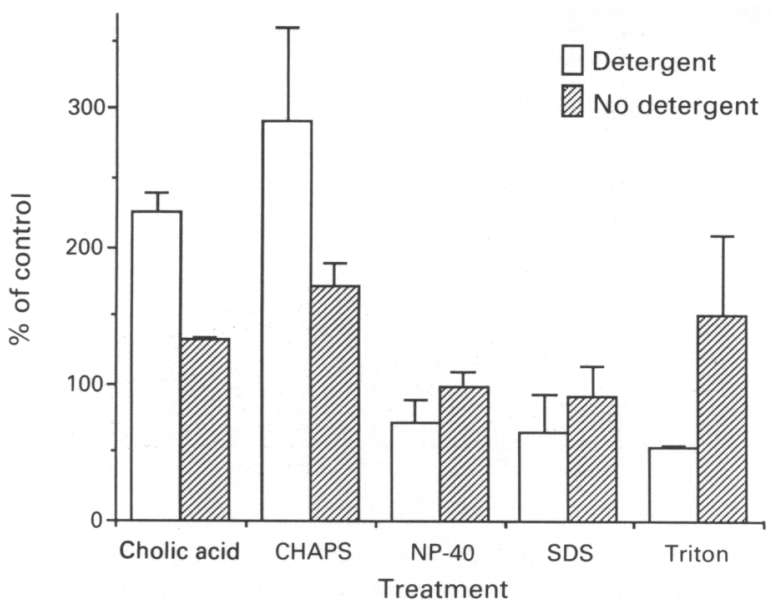

Fig. 5. Purified bovine granulosa cell plasma membranes were pre-treated for $1 \mathrm{~h}$ with $0 \cdot 1 \%$ solutions of cholic acid, CHAPS, Nonidet P-40 (NP-40), SDS, or Triton X-100. After pretreatment, the samples were washed and labelled with $\left[{ }^{3} \mathrm{H}\right]$ heparin in the presence (open bars) or absence (hatched bars) of the appropriate detergent. Values are the mean \pm s.e. of 2 separate membrane preparations.

Approximately $30 \%$ of the total heparin-binding activity present in the cavitate is lost during the $1000 \mathrm{~g}$ centrifugation (Table 2). Presumably, this is due to aggregation of basic nuclear proteins which can bind heparin non-specifically, resulting in decreased apparent specific activity of binding in the $1000 \mathrm{~g}$ pellet. All the activity present in the $1000 \mathrm{~g}$ supernatant is accounted for in the three fractions from the Percoll gradient. Approximately $1 \%$ of the $\left[{ }^{3} \mathrm{H}\right]$ heparin-binding capacity of the original cavitated sample was recovered in the plasma membrane fraction (Table 2).

\section{Factors affecting heparin binding to granulosa cell plasma membranes}

Bound $\left[{ }^{3} \mathrm{H}\right]$ heparin was displaced by incubation in media of increased ionic strength, with halfmaximal displacement $(\sim 0.4 \mathrm{pmol})$ attained at near isotonic levels of $\mathrm{NaCl}$ (Fig. 2). The $\mathrm{pH}$ of the incubation medium also affected heparin binding to the membranes (Fig. 3). Binding was enhanced at mildly acidic $\mathrm{pH}$ values with optimal binding $(1.25 \pm 0.086 \mathrm{pmol})$ occurring at $\mathrm{pH} 6.5$. However, at $\mathrm{pH}$ values above $7 \cdot 5$, binding was reduced by half from that seen at physiological $\mathrm{pH}$. The effects of elevated $\mathrm{pH}$ on heparin binding to the membranes was reversible. Membranes preincubated at $\mathrm{pH} 9.0$, washed, and subsequently re-incubated with radiolabelled heparin at $\mathrm{pH} 7.0$ bound heparin at near optimal levels (Fig. 3). Divalent cations also had an effect on the binding of heparin (Fig. 4). Exogenous magnesium added in concentrations of 10-100 mM significantly reduced binding (to $0.72 \pm 0.14 \mathrm{pmol}$, and $0.59 \pm 0.1 \mathrm{pmol}$, respectively) from control levels $(1.15 \pm 0.303 \mathrm{pmol}$ ), as did $100 \mathrm{~mm}$-calcium (reduced to $0.56 \pm 0.03 \mathrm{pmol}$ ). Addition of EDTA also decreased binding in a concentration dependent manner (reduced to $0.71 \pm 0.09 \mathrm{pmol}$ and $0.44 \pm 0.02 \mathrm{pmol}$, at 10 and $100 \mathrm{~mm}$-EDTA, respectively).

Pre-treatment of the membranes for $1 \mathrm{~h}$ with a variety of proteases effectively abolished heparin binding to the membranes (data not shown). The non-specific bacterial protease or the serine proteases chymotrypsin, trypsin, or plasmin reduced total binding to levels indistinguishable from background binding to the enzymes alone.

Detergent treatment of the membranes also had a marked effect (Fig. 5). If the assay was performed in the presence of the non-ionic detergents NP-40 or Triton X-100, binding was reduced by $30-50 \pm 4-16 \%$. Conversely, heparin binding was more than doubled $(225 \pm 15 \%)$ in the presence of the anionic detergent cholic acid and tripled $(290 \pm 67 \%)$ when binding was performed 


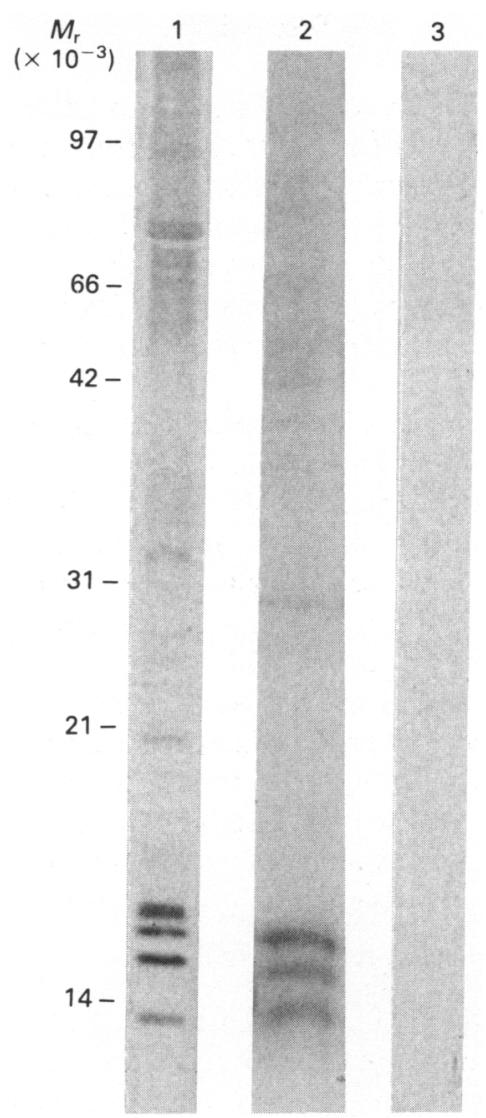

Fig. 6. Proteins present in plasma membranes purified from granulosa cells obtained from small bovine follicles, separated under non-reducing conditions. Lane 1: silver-stained sodium dodecyl sulphate-polyacrylamide gel; Lane 2: autoradiogram of nitrocellulose blot probed with ${ }^{125}$ I-labelled heparin; Lane 3: autoradiogram of nitrocellulose blot probed with ${ }^{125}$ I-labelled heparin and subsequently reincubated with $1 \mathrm{mg}$ unlabelled heparin/ml.

in the zwitterionic detergent CHAPS. Sodium dodecyl sulphate also reduced binding by $50 \%$ despite the fact that it would serve as an anionic detergent. If the detergents were washed from the filters before incubation with radiolabelled heparin, binding was restored in all cases to near control values, reversing both the inhibition or the enhancement effects caused by the various detergents (Fig. 5).

\section{Identification of heparin binding proteins}

Membrane proteins were separated by SDS-PAGE and transferred to nitrocellulose. The blots were washed free of SDS and specific binding proteins were identified by their ability to label with ${ }^{125}$ I-labelled heparin. Autoradiography of non-reduced samples indicated 3 bands with molecular weights of $M_{\mathrm{r}} 14000,15000$ and 16000 labelled most intensely with ${ }^{125}$ I-labelled heparin (Fig. 6, lane 2). These proteins labelled with ${ }^{125}$ I-labelled heparin despite the fact that insufficient quantities were present on nitrocellulose blots to visualize by Coomassie staining (data not shown). Binding was specific for these proteins, as several proteins of higher molecular weight identifiable on the silver-stained gels (Fig. 6, lane 1) remained unlabelled. Furthermore, radiolabelled heparin was completely displaced by incubation with a 500-fold excess of unlabelled heparin (Fig. 6, lane 3). 


\section{Discussion}

While it is well established that follicular GAGs can modulate granulosa cell physiology, the mechanisms by which these polysaccharides exert their effects remain unknown. Identification of specific binding moieties on the cell surface which are capable of interacting with extracellular proteoglycans/GAGs is a logical first step in examining the role of GAGs as an intrafollicular regulatory mechanism. These experiments provide a method for the rapid collection of an enriched preparation of plasma membranes from granulosa cells, describe some of the characteristics of heparin-binding domains, and identify specific heparin-binding proteins associated with those membranes.

Nitrogen cavitation and Percoll gradient centrifugation provide a number of significant advantages over previously reported techniques for obtaining plasma membranes from granulosa cells (Mintz et al., 1978). Cavitation uniformly disrupts all the cells in the suspension, requires no enzymic treatment, and provides a more homogeneous population of vesicles with fewer contaminants from other regions of the cell. Finally, the preparation and centrifugation time for the Percoll gradients are significantly less than that required for sucrose gradients normally used for subcellular fractionation (Aronson \& Touster, 1974).

Electron microscopic examination of the top band of the Percoll gradient revealed a uniform suspension of membrane vesicles with no apparent contamination from intact intracellular organelles. The morphological observations were confirmed by the marker enzyme assays, which indicated a 4-fold enrichment of 5'-nucleotidase activity in that fraction. Eight times as much of the plasma membrane marker enzyme was recovered in the purified fractions compared to the microsomal or mitochondrial enzymes glucose 6-phosphatase or succinate-cytochrome c reductase (Table 1).

Heparin is chemically similar to both heparan sulphate and dermatan sulphate, two GAGs known to be present in bovine follicular fluid (Bellin \& Ax, 1987). It therefore makes a convenient probe to examine GAG binding to isolated membranes. The current studies, using a more highly enriched and rigorously characterized preparation of plasma membranes, confirm the results of Bushmeyer et al. (1985), and indicate that the present isolation conditions had no significantly deleterious effects on binding.

Binding was reduced to half-maximal levels at isotonic concentrations of $\mathrm{NaCl}$. This is consistent with reports that binding of heparin to membrane-associated domains can be disrupted by increased ionic strength (Lobb et al., 1986). Furthermore, the gradual displacement of the radiolabel (as opposed to an all-or-none response) suggested that multiple binding domains with different affinities for heparin might be involved. It is also possible that the salt treatment alters or removes heparin-binding molecules which are loosely adsorbed to the membrane surface (Hook et al., 1984).

Heparin binding is optimized at $\mathrm{pH} 6.5$ and reduced at basic $\mathrm{pH}$, suggesting that the net electrostatic charge of the membrane is a significant factor in GAG binding to the granulosa cell surface. The enhancement of binding after pretreatment at $\mathrm{pH} \mathrm{9.0} \mathrm{may} \mathrm{be} \mathrm{due} \mathrm{to} \mathrm{solubilization} \mathrm{of}$ the membrane in the alkaline medium, exposing cryptic binding domains on specific proteins or allowing conformational changes to occur which enhance binding efficiency.

Since GAGs are highly polyanionic, divalent cations might affect heparin binding. Bushmeyer et al. (1985) reported substantial increases in heparin binding to granulosa cell membranes in the presence of both exogenous calcium and magnesium. In contrast, in the present study, both magnesium and calcium reduced binding in a dose-dependent fashion. The discrepancy is probably due to the different methods used to obtain the membrane fraction in the two studies and resultant differences in the purity of the samples. While one might expect a decrease in the net negative charge of the heparin or the membrane surface to result in increased binding, such calcium-induced inhibition has been observed in other heparin-protein interactions (Speight \& Griffith, 1983). This is apparently due to interactions of the divalent cations with the negatively charged groups of the 
sulphated amino sugars, resulting in a conformational change which is unfavourable to binding (Boyd et al., 1980). The studies using EDTA indicated that chelation of endogenous divalent cations did reduce binding significantly, suggesting that either the heparin or the membranes already contained saturating levels of cations. Failure to abolish binding completely indicates that at least a portion of the binding is independent of divalent cations.

The binding moieties were susceptible to hydrolysis by non-specific bacterial protease and serine proteases with a variety of different catalytic mechanisms. Based on other binding parameters, it is very likely the heparin binding domain(s) are receptor-like proteins embedded in the cell membrane. Plasminogen activator is a serine protease present in follicular fluid in high amounts before ovulation (Beers, 1975). Since heparin will bind to and stimulate plasminogen activator (Andrade-Gordon \& Strickland, 1986), heparin-like GAGs in follicular fluid may stimulate the hydrolysis of their own binding proteins, thereby terminating their association with the cell surface. It has been demonstrated that heparin binding to granulosa cells decreases with follicular maturation (Ax et al., 1984; Bushmeyer et al., 1985; Bellin et al., 1987b). Such a mechanism might remove the heparin-induced inhibition of progesterone secretion (Campbell \& Valiquett, 1982; Bellin et al., 1987a; Ledwitz-Rigby et al., 1987).

Heparin binding to the membranes was markedly altered by a variety of detergents and the effects of a given detergent depended on its ionic properties. The decrease of binding in SDS was probably caused by denaturation of the tertiary structure of the binding proteins. Non-ionic detergents (Nonidet P-40 and Triton X-100) probably caused exposed hydrophobic portions of the intramembranous proteins to aggregate, resulting in decreased binding. In contrast, the anionic steroid detergent cholic acid may have ionized non-polar amino acids from the hydrophobic region of the proteins, potentially increasing electrostatic interactions between the binding proteins and heparin. The zwitterionic cholic acid derivative CHAPS solubilizes membranes without causing ionization or allowing aggregation which might alter the biological activity of membrane-bound proteins (Hjelmeland, 1980). Treatment with this compound resulted in the greatest increase in heparin binding. Binding proteins may therefore possess a higher affinity for heparin than they are normally capable of expressing. This may be due to protection of potential binding sites by the lipid bilayer or by inhibition of binding to an individual protein due to steric hindrance by a molecule in its immediate vicinity topographically. If the detergents were washed from the samples before incubation with the radiolabel, binding was restored in all cases to near control levels. This indicates that, while hydrophobic interactions may influence binding, the presence of an intact lipid bilayer is not a requisite for binding activity.

Western blots probed with radiolabelled heparin identified 3 low molecular weight proteins present in plasma membranes purified from granulosa cells. The apparent molecular weights are similar to those reported for a variety of heparin-binding polypeptides which stimulate cell growth and differentiation in other tissues (Lobb et al., 1986). Reduction of disulphide bonds with $5 \%$ 2-mercaptoethanol before electrophoresis had no effect on the apparent molecular weights or ability to bind heparin of such proteins (Winer \& Ax, 1989). The same three proteins were also present in membranes from granulosa cells of medium $(5-10 \mathrm{~mm}$ diam.) and large (11-20 mm diam.) follicles, but granulosa cell membranes from small follicles appeared to bind heparin much less intensely than did those from medium or large follicles (Winer \& Ax, 1989). In Chinese hamster ovary cells mitotic activity is inversely related to the amount of surface-associated heparan sulphate (Kraemer \& Tobey, 1972), and in bovine granulosa cells the highest rate of mitotic activity is found in granulosa cells from small follicles (Priedkalns et al., 1968). These studies suggest that nonproliferating granulosa cells from larger follicles have more total binding sites for heparin. It is presently unknown what role the interactions between the heparin-binding proteins in granulosa cell membranes identified in the current study and follicular fluid proteoglycans play in follicular development.

These studies report a new method of rapidly obaining purified membranes from a limited population of granulosa cells. The characterization of the binding domains as membrane- 
associated proteins provides opportunities for numerous additional studies. Detergent solubilization of the membranes without appreciable loss in binding activity should simplify attempts to purify the binding proteins. Further analysis of the interactions of these molecules with native follicular fluid GAGs at various stages of granulosa cell development should provide useful insights into the role of complex carbohydrates in follicular maturation.

We thank Sue Bollig, Lisa Hendrickson, Kathy Horn, Shari Nass, and Dale Ripley for expert technical assistance. Research supported by the University of Wisconsin College of Agricultural and Life Sciences and USDA Grant 85-CRCR-1-1864.

\section{References}

Amsterdam, A., Riesel, R., Mintz, Y., Shemesh, M. \& Salomon, Y. (1979) Inhibition of gonadotropin sensitive adenylate cyclase by ovarian follicular fluid. Biochem. Biophys. Res. Commun. 87, 505-512.

Andrade-Gordon, P. \& Strickland, S. (1986) Interaction of heparin with plasminogen activators and plasminogen: effects on the activation of plasminogen. Biochemistry, NY 25, 4033-4040.

Aronson, N.N., Jr \& Touster, O. (1974) Isolation of rat liver plasma membrane fragments in isotonic sucrose. In Methods of Enzymology, Vol. 30, pp. 90-102. Eds S. Fleischer \& L. Packer. Academic Press, New York.

Ax, R.L. \& Bellin, M.E. (1988) Glycosaminoglycans and follicular development. J. Anim. Sci. 66 (Suppl. 2), 32-49.

Ax, R.L., Bushmeyer, S.M., Boehm, S.K. \& Bellin, M.E. (1984) Binding of the glycosaminoglycan $\left[{ }^{3} \mathrm{H}\right]$ heparin to bovine granulosa cells varies with size and estrogen content of ovarian follicles. Endocrine Res. 10, 63-72.

Ax, R.L., Bellin, M.E. \& Grimek, H.J. (1985) Properties and synthesis of glycosaminoglycans by the ovary. In Proc. 5th Ovarian Workshop, pp. 451-480. Eds D. O. Toft \& R. J. Ryan. Serono Symposium, Champaign, IL.

Ax, R.L., Stodd, C.M., Boehm, S.K. \& Bellin, M.E. (1986) Removal of glycosaminoglycans from bovine granulosa cells contributes to increased binding of hydrogen-3 heparin. J. Dairy Sci. 69, 531-534.

Beers, W.H. (1975) Follicular plasminogen and plasminogen activator and the effect of plasmin on ovarian follicular wall. Cell 6, 379-386.

Bellin, M.E. \& Ax, R.L. (1987) Purification of glycosaminoglycans from bovine follicular fluid. J. Dairy Sci. 70, 1913-1919.

Bellin, M.E., Veldhuis, J.D. \& Ax, R.L. (1987a) Follicular fluid glycosaminoglycans inhibit degradation of low density lipoproteins and progesterone production by porcine granulosa cells. Biol. Reprod. 37, 1179-1184.

Bellin, M.E., Wentworth, B.C. \& Ax, R.L. (1987b) Comparisons of the ability of follicular fluid glycosaminoglycans and chemically desulfated heparin to compete for heparin-binding sites on granulosa cells. Biol. Reprod. 37, 293-300.

Bolton, A.E. \& Hunter, W.M. (1973) The labelling of proteins to high specific radioactivities by conjugation to a ${ }^{125} \mathrm{I}$-containing acylating agent. Biochem. $J$. 133, 529-539.

Boyd, J., Williamson, F.B. \& Gettins, P. (1980) A physico-chemical study of heparin: Evidence for a calcium-induced co-operative conformational transition. J. molec. Biol. 137, 175 190.

Bradford, M.M. (1976) A rapid and sensitive method for the quantitation of microgram quantities of protein utilizing the principle of protein-dye binding. Analyt. Biochem. 72, 248-254.

Burnette, W.N. (1981) "Western Blotting": electrophoretic transfer of proteins from sodium dodecyl sulfate-polyacrylamide gels to unmodified nitrocellulose and radiographic detection with antibody and radioiodinated Protein A. Analyt. Biochem. 112, 195-203.

Bushmeyer, S.M., Bellin, M.E. \& Ax, R.L. (1985) Specific binding of $\left[{ }^{3} \mathrm{H}\right]$ heparin to bovine granulosa cell membranes. Molec. cell. Endocrinol. 42, 135-144.

Campbell, K.L. \& Valiquett, T.R. (1982) Do nonhormonal molecules cause correlated alterations of granulosa cell responses to FSH in vitro? Biol. Reprod. 26 (Suppl. 1), 102A, Abstr.

Cardin, A.D., Witt, K.R. \& Jackson, R.L. (1984) Visualization of heparin-binding proteins by ligand blotting with ${ }^{125}$ I-heparin. Analyt. Biochem. 137, 368-373.

Hegyvary, C., Kang, K. \& Bandi, Z. (1979) Automated assay of phosphohydrolases by measuring released phosphate without deproteinization. Analyt. Biochem. 94, 397-401.

Hjelmeland, L.M. (1980) A non-denaturing zwitterionic detergent for membrane biochemistry: design and synthesis. Proc. natn. Acad. Sci. USA 77, 6368-6370.

Hook, M.L., Kjellen, L., Johansson, S. \& Robinson, J. (1984) Cell surface glycosaminoglycans. Ann. Rev. Biochem. 53, 847-869.

King, T.E. (1967) Preparations of succinate-cytochrome $c$ reductase and the cytochrome $b-c_{1}$ particle, and reconstitution of succinate-cytochrome $\mathrm{c}$ reductase. In Methods of Enzymology, Vol. 10, pp. 216-225. Eds R. W. Estabrook \& M. E. Pullman. Academic Press, New York.

Kraemer, P.M. \& Tobey, R.A. (1972) Cell-cycle dependent desquamation of heparan sulfate from the cell surface. J. Cell Biol. 55, 713-717.

Laemmli, U.K. (1970) Cleavage of structural proteins during the assembly of the head of bacteriophage T4. Nature, London 277, 680-685.

Ledwitz-Rigby, F., Gross, T.M., Schjeide, O.A. \& Rigby, B.W. (1987) The glycosaminoglycan chondroitin-4sulfate alters progesterone secretion by porcine granulosa cells. Biol. Reprod. 36, 320-327. 
Lindahl, U. \& Hook, M. (1978) Glycosaminoglycans and their binding to biological macromolecules. Ann. Rev. Biochem. 47, 385-417.

Lobb, R.R., Harper, W. \& Fett, J.W. (1986) Purification of heparin-binding growth factors. Analyt. Biochem. 154, $1-14$.

Miller, D.J. \& Ax, R.L. (1988) An improved assay for measuring heparin binding to bull sperm. J. Dairy Sci. 71, 239-244.

Mintz, Y., Amir, Y., Amsterdam, A., Lindner, H.R. \& Salomon, Y. (1978) Properties of LH-sensitive adenylate cyclase in purified plasma membranes from rat ovary. Molec. cell. Endocrinol. 11, 265-283.

Nimrod, A. \& Lindner, H.R. (1980) Heparin facilitates the induction of $\mathrm{LH}$ receptors by FSH in granulosa cells cultured in serum-enriched medium. FEBS Lett. 119, 155-157.

Priedkalns, J., Weber, A.F. \& Zemjanis, R. (1968) Qualitative and quantitative morphological studies of the cells of the membrana granulosa, theca interna and corpus luteum of the bovine ovary. $Z$. Zellforsch. mikrosk. Anat. 85, 501-520.

Smith, J.W. \& Knauer, D.J. (1987) Ligand blotting with ${ }^{125}$ I-fluoresceinamine-heparin. Analyt. Biochem. 160, $105-114$.
Speight, M.O. \& Griffith, M.J. (1983) Calcium inhibits the heparin-catalyzed anti-thrombin III/thrombin reaction by decreasing the apparent binding affinity of heparin for thrombin. Archs Biochem. Biophys. 225, 958-963.

Winer, M.A. (1987) Heparin-binding to purified bovine granulosa cell plasma membranes. Biol. Reprod. 37 (Suppl. 1), 108, Abstr.

Winer, M.A. \& Ax, R.L. (1989) Heparin binding proteins in purified plasma membranes of bovine granulosa cells. In Paracrine Communication in the Ovary. Ontogenesis and Growth Factors. Serono Symposium, Champaign, IL (In press).

Winterbourne, D.J. \& Mora, P.T. (1981) Cells selected for high tumorogenicity or transformed by Simian Virus 40 synthesize heparan sulfate with reduced degree of sulfation. $J$. biol. Chem. 256, 4310-4320.

Wray, W., Boulikas, T., Wray, V.P. \& Hancock, R. (1981) Silver staining of proteins in polyacrylamide gels. Analyt. Biochem. 118, 197-203.

Received 7 February 1989 